\section{MEASURING INTERNATIONAL ARMS TRANSFERS}

\author{
PAUL HOLTOM, MARK BROMLEY AND VERENA SIMMEL
}

The collection and analysis of consistent and comprehensive data on international arms transfers enables the identification over time of trends in international arms transfers, providing reliable information on suppliers and recipients as well as types and volumes of conventional arms being transferred. Data on arms exports provides an indication of the importance of the arms industry for trade; an overview of the main recipients of arms and the main types of arms being exported; and an opportunity to assess arms export policies in the context of international and national law.

This Fact Sheet describes three sources of information for measuring international arms transfers: SIPRI's measure of the volume of arms transfers; the financial value estimate of the United States Congressional Research Service (CRS); and national government data on the financial value of arms export agreements and deliveries. Using German arms exports in 2011 as a case study, it compares the methods used by SIPRI, the CRS and the German Government to measure German arms exports.

\section{METHODS FOR MEASURING INTERNATIONAL ARMS TRANSFERS}

The differences between the various methods for measuring international arms transfers reflect both the purpose of the measurement and the availability of data. For example, one method might be most useful for attempting to assess the importance of arms exports for a national economy, while another seeks to measure the transfer of military capability. Two factors related to the availability of data that affect overall measurements are the definition of the arms to be measured and the units of measurementwhether the estimate is based on the number of weapons, the financial value of sales, the unit production costs, or some other unit. This section briefly describes the methods used by SIPRI, the CRS and national governments when measuring the volume or financial value of arms exports.

\section{SIPRI's method}

SIPRI has developed a unique pricing system to measure the volume of deliveries of major conventional weapons and components using a common unitthe SIPRI trend-indicator value (TIV). The TIV of an item being delivered is intended to reflect its military capability rather than its financial value. This common unit can be used to measure trends in the flow of arms between particular countries and regions over time-in effect, a military capability price index. Therefore, it is important to ensure that the pricing system remains

\section{KEY FACTS}

- Consistent, comprehensive data on international arms transfers enables the identification over time of trends in international arms transfers at the global, regional and national levels. There are several different methods for measuring international arms transfers.

- SIPRI uses a unique pricing system, the trend-indicator value (TIV), to measure the volume of deliveries of major conventional weapons. The SIPRI TIV measures transfers of military capability rather than the financial value of arms transfers.

- The US Congressional Research Service (CRS) provides data on the financial value of international arms transfers.

- A number of states also provide data on the financial value of their arms exports.

- The volume of German arms export deliveries in 2011 amounted to 1.2 billion TIV according to SIPRI, $\$ 1.6$ billion according to the CRS and $€ 1.3$ billion ( $\$ 1.65$ billion) according to the German Government.

- Germany ranked as the 5th largest exporter of major conventional weapons in 2011 according to SIPRI and the 6th largest according to the CRS. 
Box 1. Major conventional weapons and components covered by the SIPRI Arms Transfers Database

The SIPRI Arms Transfers Database records transfers of the following major conventional weapons and components:

- aircraft, both fixed wing and rotary (including unmanned)

- armoured vehicles, including tanks, armoured personnel carriers and infantry fighting vehicles

- artillery above 100-millimetres in calibre

- sensors (radars, sonars and many passive electronic sensors)

- air defence missile systems and large air defence guns

- guided missiles, torpedoes, bombs and shells

- ships with 100 tonne displacement or more, armed with 100-mm calibre artillery, torpedoes or guided missiles

- engines for combat-capable aircraft, large military aircraft, combat ships, large support ships and armoured vehicles

- gun or missile-armed turrets for armoured vehicles and ships

- reconnaissance satellites

- air refuelling systems

The database also includes licensed production, the SIPRI definition of which covers a range of activities whereby the recipient is granted permission to produce major conventional weapons from kits or blueprints provided by a foreign supplier. The SIPRI Arms Transfers Database does not include transfers of small arms, trucks, ammunition, support equipment, services or technology, and most light weapons and components.

Source: SIPRI Arms Transfers Database, 'Coverage', <http://www.sipri.org/databases/armstransfers/background/coverage/>.

consistent across both the weapon systems covered and over time, and that any changes introduced are backdated. ${ }^{1}$

Each weapon that falls within the SIPRI definition of major conventional arms (see box 1) is given a TIV. The TIV is derived from the known unit production costs of a core set of weapons. The TIV for a weapon whose unit production cost is unknown is calculated by making a comparison with core weapons based on the following elements: size and performance characteristics (i.e. weight, speed, range and payload); types of electronics, loading or unloading arrangements, engine, tracks or wheels, armament, and materials; and finally the era in which the weapon was produced. Weapons that have previously been used by another armed force (i.e. surplus weapons) are given a value equal to 40 per cent of that of a new weapon. Used weapons that have been significantly refurbished or modified by the supplier before delivery are given a value of 66 per cent of the value when new. (See box 2 for examples illustrating how the TIV of a transfer of arms is calculated). The overall volume of arms exports from a particular state in any given year is then calculated by adding together the TIVs for the weapons and components delivered. Since year-on-year deliveries can fluctuate, SIPRI uses 5-year moving averages to provide a more stable measure for trends in international arms transfers.

The SIPRI TIV is often misinterpreted as a financial value. However, it neither reflects the actual price paid for weapons nor represents current dollar values for arms transfers. The TIV should therefore not be compared directly with gross national product (GNP), gross domestic product (GDP), military expenditure, sales values or the financial value of arms export licences. However, TIVs can be used as the raw data for calculating trends in international arms transfers over periods of time; indicative global percent-

\footnotetext{
${ }^{1}$ For more information on the SIPRI methodology see Holtom, P., Bromley, M., Wezeman, P. D. and Wezeman, S. T., 'Developments in arms transfers in 2011', SIPRI Yearbook 2012: Armaments, Disarmament and International Security (Oxford University Press: Oxford, 2012), pp. 273-77.
} 
Box 2. Sample calculations of the SIPRI trend-indicator value

Transfer of newly produced complete weapons systems

In 2011 Germany delivered three $80 \mathrm{~m}$ offshore patrol vessel (OPV-80; Bruneian designation is Darussalam) corvettes to Brunei Darussalam. One OPV-80 is valued at 63 million SIPRI TIV; the delivery of three OPV-80 was therefore valued at 189 million TIV. There is no publicly reported data on the financial value of the deal.

Transfer of used weapons

In 2011 Germany delivered an estimated 7 surplus Marder-1A3 infantry fighting vehicles (IFVs) to Chile. SIPRI values used weapons at 40 per cent of the TIV of a new weapon. A new Marder-1A3 IFV is valued at 1.75 million TIV, so a used version is valued at 0.7 million TIV. The delivery of the 7 surplus IFVs to Chile was therefore valued at 4.9 million TIV. The publicly reported financial value of the deal for 146 Marder-1A3 IFVs was $€ 7.3$ million (\$9.5 million).

Transfer of used weapons that have been significantly refurbished or modified

In 2011 Germany delivered 59 significantly refurbished Leopard-2A4 tanks to Singapore. SIPRI values used weapons that have been significantly refurbished or modified at 66 per cent of the TIV of a new weapon. A new Leopard-2A4 tank is valued at 4 million TIV, so a significantly refurbished version is valued at 2.64 million TIV. The delivery of 59 significantly refurbished Leopard-2A4 tanks was therefore valued at 155.76 million TIV. There is no publicly reported data on the financial value of the deal.

Transfer of significant components for major conventional weapons systems

In 2011 Germany delivered an estimated 40 MTU-183 diesel engines to Spain for installation in the latter's indigenously produced Pizarro (ASCOD) infantry fighting vehicles (IFV). Each MTU-183 diesel engine is valued at 0.1 million TIV, so the delivery of 40 engines was valued at 4 million TIV. There is no publicly reported data on the financial value of the deal.

Licensed production arrangement

In 2011 an estimated 55 UH-72A Lakota helicopters based on Eurocopter's EC-145 helicopter were produced under a German licence in the USA and entered into US service. One UH-72A Lakota (EC-145) helicopter is valued at 2.2 million TIV; the production under licence of $55 \mathrm{UH}-72 \mathrm{~A}$ Lakota helicopters in 2011 is therefore valued at 121 million TIV. The publicly reported financial value of the deal for the production of 345 helicopters was $\$ 3$ billion, including $\$ 2$ billion for 20 years of support.

Source: SIPRI Arms Transfers Database, <http://www.sipri.org/databases/armstransfers>.

ages for suppliers and recipients; and percentages for the volume of transfers to or from particular states.

\section{The US Congressional Research Service's method}

The CRS annual report Conventional Arms Transfers to Developing Nations aims to assist the US Congress 'in its oversight role of assessing how the current nature of the international weapons trade might affect U.S. national interests'. ${ }^{2}$ Despite its title, the report provides the estimated financial value of arms export agreements and deliveries from the largest arms exporters to all regions of the world in constant and current US dollars for the previous eight calendar years. The CRS report covers transfers to governments of 'all categories of weapons and ammunition, military spare parts, military construction, military assistance and training programs, and all associated services'. ${ }^{3}$ This definition is much broader than SIPRI's.

For data on US arms export agreements and deliveries, the CRS report relies on information on government-to-government Foreign Military Sales

\footnotetext{
${ }^{2}$ Grimmett, R. F. and Kerr, P. K., Conventional Arms Transfers to Developing Nations, 2004-2011, Congressional Research Service (CRS) Report for Congress R42678 (US Congress, CRS: Washington, DC, 24 Aug. 2012), p. 1.

${ }^{3}$ Grimmett and Kerr (note 2), p. 2.
} 
(FMS). ${ }^{4}$ On the sources of data for non-US countries, the CRS simply states that 'Statistics for foreign countries are based upon estimated selling prices', although it is believed that the CRS draws on classified US Government sources. ${ }^{5}$ CRS figures for non-US arms exporters are often lower than official government financial values for export licences granted and arms exports.

\section{National methods}

SIPRI has identified 34 states that have provided official data on the financial value of their 'arms exports', 'licences for arms exports' or 'arms export agreements' to the public for at least 6 years in the period 2001-10 and for which the average of the reported values exceeds $\$ 10$ million. ${ }^{6}$ This official data can be provided either in a national report on arms exports, another type of government report, a press release or via an attributed or unattributed quote in a media report. ${ }^{7}$

Public statements on the financial value of states' arms exports cannot be easily compared due to differences in the definitions of 'arms' used and the fact that many states provide information only on the financial value of either proposed arms exports or completed deliveries. Information on the value of proposed arms exports and completed deliveries of arms refer to different activities, and so should not be directly compared.

States use different methods for collecting and reporting information on the financial value of proposed arms exports or completed deliveries. Data on proposed arms exports can be based on the value of either arms export agreements concluded or export licences issued, which represent two different data sets. Data on deliveries of arms can be based on data provided by the national customs authorities or company reporting on export licences used, which again represent two different data sets.

\section{MEASURING GERMAN ARMS EXPORTS IN 2011}

Taking the example of Germany in 2011, this section shows how the three types of estimate work in practice. The three methods provide different estimates of the magnitude of Germany's arms exports and of Germany's ranking among arms exporters; a longer-term view shows that the annual volume or value of deliveries can fluctuate quite significantly for all three methods described (see table 2 and figures 1-3). However, they all show that Germany is among the world's largest arms exporters.

\footnotetext{
${ }^{4}$ Grimmett and Kerr (note 2), p. 19. There are two main avenues through which military equipment is exported from the USA: the government-to-government FMS programme administered by the Department of Defense and the Direct Commercial Sales (DCS) programme administered by the Department of State. See Stohl, R. and Schroeder, M., 'US export controls', SIPRI Yearbook 2005: Armaments, Disarmament and International Security (Oxford University Press: Oxford, 2005), pp.720-40. The value of commercial exports licensed under the DCS programme has been excluded from recent editions of the CRS report because of doubts about the quality of the data.

${ }^{5}$ Grimmett and Kerr (note 2), p. 35; and Federation of American Scientists, 'Literature review: CRS' conventional arms transfers to the third world', Arms Sales Monitor, no. 6 (Aug. 1991).

${ }^{6}$ Bromley, M., 'The financial value of state's arms exports, 2001-10', SIPRI Yearbook 2012 (note 1), pp. 303-305

${ }^{7}$ Weber, H. and Bromley, M., 'National reports on arms exports', SIPRI Fact Sheet, Mar. 2011, $<$ http://books.sipri.org/product_info?c_product_id=423>.
} 
Table 1. Ranking Germany as a global arms exporter, 2002-11

\begin{tabular}{lllllllllll}
\hline Source & 2002 & 2003 & 2004 & 2005 & 2006 & 2007 & 2008 & 2009 & 2010 & 2011 \\
\hline SIPRI & 5 & 3 & 5 & 3 & 3 & 3 & 3 & 3 & 3 & 5 \\
US Congressional Research Service &. & $\ldots$ & 5 & 5 & 4 & 3 & 3 & 3 & 5 & 6 \\
Government data $^{a}$ & 8 & 5 & 5 & 5 & 5 & 5 & 5 & 6 & 4 &.. \\
\hline
\end{tabular}

${ }^{a}$ These rankings use official data provided by states. They are not based on a comparison of the same data sets for all states. Not all states that provide information on the financial value of their arms exports provide information for both the financial value of export licences issued or arms transfer agreements concluded and deliveries of arms and other military equipment.

The United Kingdom stopped providing information on exports of defence equipment and additional aerospace equipment and services in 2008. Israel stopped providing such information in 2006. China has never published information on its arms exports.

\section{SIPRI's estimate}

The SIPRI estimate of the volume of German arms exports in 2011 was 1.2 billion TIV, or 4 per cent of global arms exports, down from 2.5 billion TIV in 2010 (10 per cent of the world total). ${ }^{8}$ SIPRI estimated Germany to be the fifth largest exporter of major conventional weapons in 2011, behind the USA, Russia, France and China. (See figure 1 and table 1 for the longer-term trend.)

The major recipients of German arms exports in 2011 were Brunei Darussalam (accounting for 16 per cent of exports), USA (11 per cent), Singapore (7 per cent), Spain (7 per cent) and Taiwan (6 per cent). Tanks and armoured vehicles represented 26 per cent of the volume of German major conventional weapons exports in 2011, with ships accounting for 22 per cent, engines 20 per cent, and missiles 15 per cent. (See box 2 for some examples of the TIV of German arms exports in 2011.)

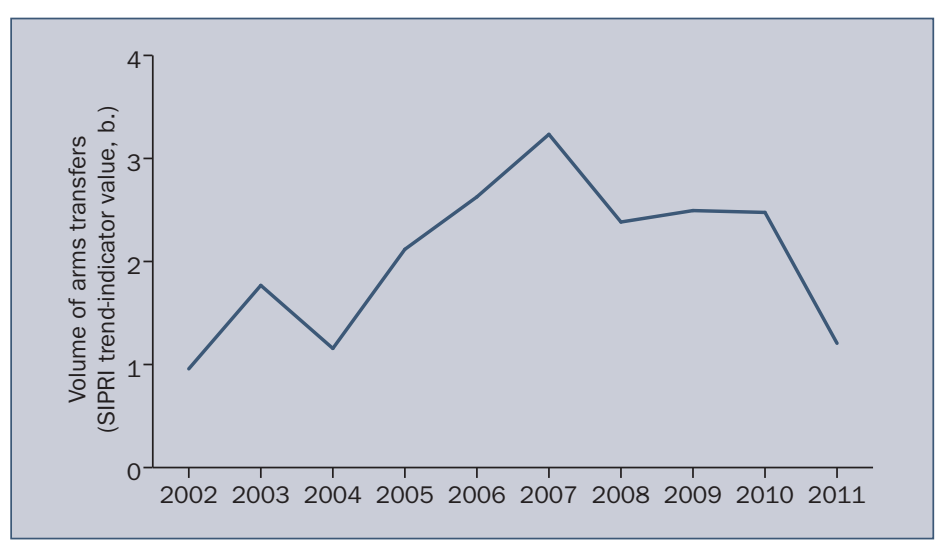

Figure 1. SIPRI's estimate of Germany's arms exports, 2002-11

Source: SIPRI Arms Transfers Database, <http://www.sipri.org/data bases/armstransfers>.

\section{The US Congressional Research Service's estimate}

The CRS estimated the financial value of German arms deliveries in 2011 to be $\$ 1.6$ billion (in 2011 US dollars), or approximately 4 per cent of global arms exports. ${ }^{9}$ This ranked Germany as the sixth largest exporter of major conventional weapons in 2011, behind the USA, Russia, the UK, France and Italy. (See figure 2 and table 1 for the longer-term trend.)

The CRS data is not sufficiently detailed to gain an understanding of which deliveries account for the stated value of German arms exports. The CRS report includes tables detailing the numbers of weapon systems delivered, but these are aggregated over 3-year periods and by weapon category and

\footnotetext{
${ }^{8}$ Dramatic year-on-year changes such as this are avoided by SIPRI's use of 5-year moving averages. To allow comparison with the other types of measure, single year figures are given here.

${ }^{9}$ Grimmett, R. F., Conventional Arms Transfers to Developing Nations, 2003-2010, Congressional Research Service (CRS) Report for Congress R42017 (US Congress, CRS: Washington, DC, 22 Sep. 2011), p. 77.
} 


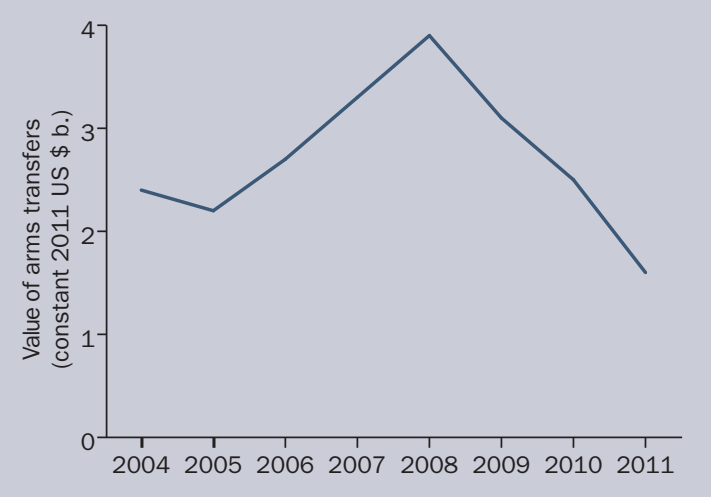

Figure 2. The US Congressional Research Service's estimate of Germany's arms exports, 2004-11

Source: Grimmett, R. F. and Kerr, P. K., Conventional Arms Transfers to Developing Nations, 2004-2011, Congressional Research Service (CRS) Report for Congress R42678 (US Congress, CRS: Washington, DC, 24 Aug. 2012).

region, rather than weapon description and destination. Further, there is no separate entry for German exports. ${ }^{10}$

According to the CRS, the financial value of German arms transfer agreements concluded in 2011 totalled $\$ 100$ million (in current US dollars), or 0.1 per cent of the global total value of arms transfer agreements, ranking Germany as the 7th largest supplier listed by CRS. ${ }^{11}$ There is insufficient open source information in the SIPRI Arms Transfers Database on the financial value of arms transfer agreements concluded by Germany in 2011 to corroborate this figure. However, comparisons between CRS data on arms transfer agreements and publicly reported information on the value of signed arms export contracts in previous years indicates a tendency for CRS to underestimate the financial value of arms transfer agreements for states other than the USA. For example, the $2007 \mathrm{CRS}$ report stated that the financialvalue of Germany's arms export agreements with developing countries in 2006 was \$1.9billion,based on'anagreementwithBrazilforlicensedproductionofaType ILK214submarineand theupgradingoffiveexistingType209submarines, and from an Israeli order for two Type 800 Dolphin class submarines, ${ }^{12}$ However, according to available open sources, the Brazil deal was worth approximately $\$ 1.6$ billion and the Israel deal was worth $\$ 1$ billion. This gives a combined value of at least $\$ 2.6$ billion $-\$ 700$ million more than the CRS estimatewithout taking into account other agreements concluded by Germany in $2006 .{ }^{13}$

\section{The German Government's official value}

The German Government has published a national report on military equipment exports (Rüstungsexportbericht) every year since 1999. ${ }^{14}$ The report provides information on (a) the financial value of export licences granted and completed deliveries of 'war weapons' (Kriegswaffen); and (b) the financial value of export licences granted for military equipment as defined in the German national control list (i.e. which includes both war weapons and other military equipment that requires an export licence). ${ }^{15}$ Thus, German

\footnotetext{
${ }^{10}$ Grimmett (note 9), pp. 63-67.

${ }^{11}$ Grimmett (note 9), p. 27.

12 Grimmett, R. F., Conventional Arms Transfers to Developing Nations, 1999-2006, Congressional Research Service (CRS) Report for Congress RL34187 (US Congress, CRS: Washington, DC, 26 Sep. 2007), p. 13.

${ }^{13}$ SIPRI Arms Transfers Database, <http://www.sipri.org/databases/armstransfers>.

${ }^{14}$ German Ministry of Economics and Technology (BMWi), Bericht der Bundesregierung über ihre Exportpolitik für konventionelle Rüstungsgüter: Rüstungsexportbericht, 1999-2011 [Report of the federal government on its export policy for conventional military equipment: report on military equipment exports, 1999-2011] (BMWi: Berlin, 2000-12).

15 Gesetz über die Kontrolle von Kriegswaffen (Kriegswaffenkontrollgesetz) [War Weapons Control Act], as amended up to 11 Oct. 2002, section 12a., English translation, <http://www.bafa. de/bafa/en/export_control/legislation/export_control_cwc_p_war_weapons_control_act.pdf>. While German companies are obliged to report deliveries of items covered by the war weapons list
} 
official data on the financial value of arms export deliveries does not include the value of the many items on the German national control list that are not classed as war weapons. (See figure 2 and table 1 for the longer-term trend.)

The reported financial value of German deliveries of war weapons in 2011 was $€ 1.3$ billion ( $\$ 1.65$ billion), compared to $€ 2.1$ billion ( $\$ 2.8$ billion) in 2010 . Several major suppliers have not yet provided the financial value of their arms deliveries in 2011, and so a comparison of the German Government's official financial value with its peers cannot be made for 2011. In 2010, in terms of the financial value of deliveries of military equipment, Germany ranked as the fourth largest arms exporter behind the USA, Russia and France. ${ }^{16}$ However, in this case the German data is based solely on reporting on war weapons, which is a narrower range of items than those covered by the US, Russian and French

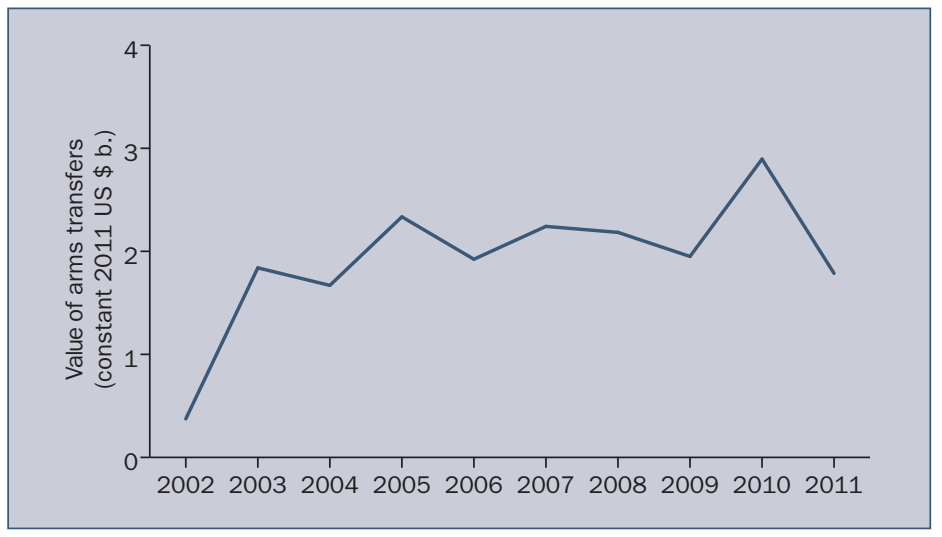

Figure 3. The German Government's estimate of Germany's arms exports, 2002-11

Source: German Ministry of Economics and Technology (BMWi), Bericht der Bundesregierung über ihre Exportpolitik für konventionelle Rüstungsgüter: Rüstungsexportbericht, 1999-2010 [Report of the federal government on its export policy for conventional military equipment: report on military equipment exports, 1999-2010] (BMWi: Berlin, 2000-11). data. In addition, such major exporters as China, Israel and the United Kingdom do not provide information on the financial value of their arms deliveries.

According to the German arms export report, Germany granted 17586 single export licences in 2011, worth a total of $€ 5.4$ billion ( $\$ 6.9$ billion), compared with $€ 4.7$ billion ( $\$ 6.3$ billion) in $2010 .{ }^{17}$ Of this total, $€ 1.65$ billion ( $\$ 2.1$ billion), or approximately 31 per cent, was for export licences for war weapons. In 2010 Germany ranked as the fifth largest state in terms of the financial value of proposed exports of military equipment, behind the USA, the UK, Israel and France. ${ }^{18}$

\section{COMPARING THE ESTIMATES}

The fact that the SIPRI TIV figure sometimes closely matches estimates and official financial values for arms exports has no doubt contributed to the misconception that the SIPRI TIV figure is a financial value for arms exports. Purely by coincidence, in the case of Germany the SIPRI TIV figure of 1.2 billion TIV, the CRS financial value of $\$ 1.6$ billion and the national government figure of $\$ 1.65$ billion are all close (see table 2). However, each method uses a different unit of measurement, relies on different sources of data and uses a different definition of 'arms'.

In particular, the CRS definition is broader than both SIPRI's definition and the German definition of 'war weapons'; this strengthens the view that

to the German export control agency, there is no matching obligation to report on deliveries of items on the German national control list that are not war weapons.

${ }^{16}$ Bromley (note 6). This ranking is based on a comparison of publicly available information on the financial value of deliveries.

17 In addition, the German Government granted 91 collective project (general) licences for military equipment in 2011, worth $€ 5.38$ billion. German Ministry of Economics and Technology (note 14).

18 Bromley (note 6), pp. 304-305. This ranking is based on a comparison of publicly available information on export licences issued, as well as orders and arms transfer agreements. 
SIPRI is an independent international institute dedicated to research into conflict, armaments, arms control and disarmament. Established in 1966, SIPRI provides data, analysis and recommendations, based on open sources, to policymakers, researchers, media and the interested public.

\section{GOVERNING BOARD}

Göran Lennmarker, Chairman (Sweden)

Dr Dewi Fortuna Anwar

(Indonesia)

Dr Vladimir Baranovsky (Russia)

Ambassador Lakhdar Brahimi (Algeria)

Jayantha Dhanapala

(Sri Lanka)

Susan Eisenhower

(United States)

Ambassador Wolfgang

Ischinger (Germany)

Professor Mary Kaldor

(United Kingdom)

The Director

\section{ACTING DIRECTOR}

Jakob Hallgren (Sweden)

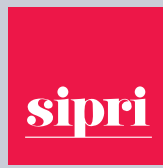

STOCKHOLM INTERNATIONAL PEACE RESEARCH INSTITUTE Signalistgatan 9 SE-169 70 Solna, Sweden Telephone: +4686559700 Fax: +4686559733

Email:sipri@sipri.org Internet: www.sipri.org
Table 2. Measuring German arms exports, 2011

\begin{tabular}{|c|c|c|c|c|}
\hline Source of data & $\begin{array}{l}\text { Value of deals, } \\
\text { export licences } \\
\text { issued or arms } \\
\text { sales agreements }\end{array}$ & Ranking & $\begin{array}{l}\text { Volume or value } \\
\text { of arms deliveries }\end{array}$ & Ranking \\
\hline SIPRI & . & . & 1.2 billion TIV & 5 th \\
\hline $\begin{array}{l}\text { US Congressional } \\
\text { Research Service }\end{array}$ & $\$ 100$ million & 7 th & $\$ 1.6$ billion & 6 th \\
\hline German Government & $\begin{array}{l}€ 5.4 \text { billion } \\
\text { ( } \$ 6.9 \text { billion) }\end{array}$ & . & $\begin{array}{l}€ 1.3 \text { billion } \\
(\$ 1.65 \text { billion })^{a}\end{array}$ & . \\
\hline
\end{tabular}

$\mathrm{TIV}=$ trend-indicator value.

a This figure is for exports of 'weapons of war' and so covers a narrower category of arms than the German Government figure for export licences issued.

the CRS estimate for German arms exports is an underestimate. However, increasing the CRS estimate for German arms exports may not result in a change in the relative rankings of the major arms exporters or their shares of global arms transfers, as the CRS estimates for the UK and China-two of the states ranked above Germany in 2011 by the CRS-may also be underestimates.

The methods also differ in the aspect of the arms trade that they try to measure. While the SIPRI estimate measures transfers of military capability, the CRS and most national estimates measure exports in terms of their financial value. Offsets, military aid arrangements and donations mean that the nominal financial value of many arms deals reflects neither the costs of production nor the objective military utility of the arms exported. Indeed, none of the three methods outlined provides a perfect way to measure international arms transfers because they all suffer from the fact that not all states provide reliable data-in terms of volume (units) or financial value-on their arms exports.

\section{ABOUT THE AUTHORS}

Dr Paul Holtom (United Kingdom) is Director of the SIPRI Arms Transfers Programme.

Mark Bromley (United Kingdom) is a Senior Researcher with the SIPRI Arms Transfers Programme.

Verena Simmel (Germany) was an research intern with the SIPRI Arms Transfers Programme in 2011. She is currently writing her master's thesis on German arms exports at the Ludwig Maximilian University of Munich. 